\title{
A Study on Student's Perception towards Online Classes and Effectiveness in Enhancing Active Participation and Communication Skills
}

\author{
Asha Nair Ganeser \\ Faculty of Communication, Arts and Media, International University of Malaya Wales (IUMW), Kuala Lumpur, Malaysia
}

Received August 19, 2020; Revised September 30, 2020; Accepted October 24, 2020

\section{Cite This Paper in the following Citation Styles}

(a): [1] Asha Nair Ganeser, "A Study on Students' Perception of Online Classes and Effectiveness in Enhancing Active Participation and Communication Skills," Universal Journal of Educational Research, Vol. 8, No. 11B, pp. 5958 - 5964, 2020. DOI: 10.13189/ujer.2020.082231.

(b): Asha Nair Ganeser (2020). A Study on Students' Perception of Online Classes and Effectiveness in Enhancing Active Participation and Communication Skills. Universal Journal of Educational Research, 8(11B), 5958 - 5964. DOI: 10.13189/ujer.2020.082231.

Copyright $\bigcirc 2020$ by authors, all rights reserved. Authors agree that this article remains permanently open access under the terms of the Creative Commons Attribution License 4.0 International License

\begin{abstract}
Online classes are now in demand, which fit the needs of today's 21 st-century skills. The integration of technology in teaching and learning implemented as such is leading from face to face classroom learning to online learning. Educators contribute in making sure the content is fully interactive and useful for the process of learning. Various tools are embedded to facilitate the teaching and learning process and to venture students towards the world of virtual learning. This study aimed to examine students' perceptions of the English for Professional Communication online classes and how it enhances the participation and communication skills of students. This study conducted in a private higher education institution based in Kuala Lumpur and the participants were $(\mathrm{N}=50)$. Data were analyzed using SPSS. This study uses quantitative analysis where participants needed to answer a set of questionnaires. Findings are shown in the form of frequency and percentages based on responses to each variable. The result shows that students show active participation and agreed that online learning does enhance communication skills. Besides, creativity was found to be an added value for students to take up online classes. Some suggestion has been made through its findings.
\end{abstract}

Keywords Perception, Online Classes, Active Participation, Communication Skills

\section{Introduction}

The world of education has changed gradually over the years, from traditional to digitalized education. Face to face education has now replaced with online education which chalk and marker pen were replaced by e-books and printed materials [1]. These changes made the information and communication technology (ICT) a vital aspect of the education sector. They transformed the teaching and learning process in many ways [2]. On top of that, using e-learning increases HOTS skills, problem-solving, as well as the effectiveness of teaching and learning [3]. The integration of e-learning in teaching the English Language encourages students to increase their learning abilities in the aspect of 4 skills: listening, speaking, reading, and writing. As mentioned by Al-Hassan \& Shukri [4], e-learning allows students to have diverse communication ability in English by collaborating with other students in the virtual world.

Moreover, as mentioned by Danesh, Bailey, and Whisenand [5], using a computer-based lesson that we called as online learning can improve communication skills and creates a positive learning environment. The digitalized online classes are involved with strategic and innovative processes. By incorporating various tools such as podcasts, learning management systems, and blogs, it can leverage students learning and assist lecturers in producing excellent and creative content in a structured 
way [6]. The current study examines students' perceptions of online classes and the effectiveness in enhancing active participation and communication skills.

\section{The objectives as follows:}

- To identify the perception of English for professional communication class students towards online classes

- To discover the effectiveness of using online classes in enhancing student's active participation and communication skills

\section{Research questions}

- What is the perception of English for professional communication class students towards online classes?

- What is effectiveness of online classes in enhancing student's active participation and communication skills?

\section{Significant of study}

Various tools and strategies have been embedded in online classes worldwide to cater to good and quality education. As mentioned by Rhode, Richter, Gowen, Miller, and Wills [7], using a learning management system gives students more independence for students to learn at any time and location without barriers. The usage of online classes is introduced widely to most schools and universities in Malaysia, especially during the COVID-19 pandemic situation. Online classes allow lecturers to interact online synchronously by using updated features such as video conferencing, online quizzes, mind mapping, collaborative learning, and more [8]. As Agustina and Budhisantosa [9] said, online learning gives a positive result in terms of motivation, and it is a useful method when it comes to learning grammar. There are many studies on the implementation of online learning. Thus, it is essential to highlight student's perception of taking up English for Professional communication subject through online classes and its contribution towards students' participation and communication.

\section{Literature Review}

Many researchers have done various studies related to online classes and the importance of teaching and learning. Researchers from different parts of the world and the field of expertise had shared their findings and reflect on the effectiveness of online teaching and learning. The outcome of engaging students through an online environment varies according to the scope of the study.

\section{Concept of e-learning}

The idea of e-learning comes from a few combinations.
It comprises of using information technology in integrating with the education system. The e-learning embeds with operating systems, MS Office, and other learning applications through hardware comprises of tablets, desktop or laptop, and software. These tools are installed either for face-to-face or online classes. The result is to maximize the lecturer and student interaction. According to Sangra et al. [10], the concept of e-learning can be portrayed as learning which utilizes innovation and other educational model based on electronic media and tools. In the end, it is for enhancing the interaction and training that helps in establishing knowledge. However, later Singh and Thurman [11], further elaborated e-learning as an experience of involving in both synchronous and asynchronous environments by incorporating multiple smart gadgets. As such, this will provide a useful pathway for students to be accessible in their learning process.

\section{Advantage and disadvantage of online classes in education}

There are advantages and disadvantages of online classes in education. Some studies have shown the strength of online classes as the ability to fulfil the student's needs. As said by Cojocariu et al. [12], online classes provide students with flexibility in terms of learning, regardless of place and time without any restrictions by utilizing smart devices. On top of that, Aydin [13], mentioned that online classes give the space for interaction between teacher and students as for online discussion and allows communication to be an essential aspect of learning. According to Kolås [14], an interactive tool embedded in online classes creates students to be motivated and engaging towards their learning journey. However, some disadvantages occur during the implementation. Sanjay and Narayana [15] said there is a massive change in the educational models when it comes to implementing online classes where the adaptation process is longer. Students might face difficulties in handling it in the first place. Moreover, there are some challenges faced when it comes to adult students in using online classes. It will be a new scope altogether since they might have less knowledge in digital tools which requires them to have more guidance to succeed in online classes [16].

\section{Student's perception towards online classes}

In one of the research studies conducted by Koohang, Paliszkiewicz, Klein, and Nord [17], mentioned that online learning creates active participation among students. Adding on to that, Cole et al.'s [18] explain that some students choose online classes as the best solution than face-to-face as it creates an interest for students to participate in the online classes actively. On top of that, Hase and Kenyon [19] explain that several students disagree with online classes because it has an impact on 
their eye fatigue, which can cause problems in the visual aspect. As mentioned by Thamarana [20], and supported by Felix [21], in cooperating various tools such as Zoom, G-suite cloud meeting, and Superstar provides added value in the learning process. In the end, it creates positive results in enhancing students' interest in learning.

\section{Effects towards student's communication and participation}

Many research studies have been conducted regarding the student's effects on communication and participation in different perspectives. Salbego and Tumolo [22] conduct a study to investigate the student's experiences in skype language classes. It shows that there is an increase in the development of a student's language skills. On top of that, Joksimović et al. [23] mentioned that online classes encourage learners to communicate with peers actively. As such, that factor contributes well to the participation and involvement of each student in the online class. Nevertheless, online classes have greater control over the timing of completing the coursework, which creates a new solution for students to manage their time effectively without full guidance by lecturers [24].

Also, online learning improves students' academic performance as compared to face-to-face class [25]. In addition to that, [26] mentioned that audio feedback through online class is more effective as the communication is clear. Students seem to feel the sense of care given by the lecturer and make them more engaging in the online lesson. There are many findings collected to measure students' perceptions and the effectiveness of online classes in different fields. However, less focus is given to how much they perceived their learning, participation as well as the level of communication skills, specifically in English for Professional Communication subject.

\section{Methodology}

The method which was used is quantitative. Online survey questionnaires were constructed based on previous literature to answer the research question, which is listed above. In total, 50 students participated in as respondents of this research, and all of them were students from a private university who took English for Professional Communication online classes. The age of the respondents ranges between 18 and 27. The questionnaire was distributed through a Learning Management System called
Open Learning. Respondents answered the questionnaire through the said platform. There are a few pages that the respondent should answer. The first page consists of the consent form to make sure he or she agrees to the description written under the consent section, followed by demographic questions. The third section is to measure student perception on online learning, followed by the final part to evaluate the effects of enhancing active participation and communication. The collected data were analyzed by using SPSS version 25 . The descriptive analysis, which included frequency and percentages, is presented in this study.

\section{Results and Findings}

The questionnaires are created to identify student's perception of online classes, and tables of findings are listed below according to the questions. Data were analyzed using descriptive statistics and listed in the form of table to explain further the frequency and percentages of the perception and the effectiveness of active participation and communication according to categories.

Table 1 shows student's perception of online classes. The summary is created according to the responses given by the students on four-pointer Likert scale namely strongly disagree (SD), disagree (D), agree (A) and strongly agree (SA) along with the percentages. It shows that most students agree that online learning create them to be more innovative and easier for them to learn in their own pace. It represents $40 \%, 54 \%$ and $48 \%$ respectively. Besides, for "student's access lecture notes anywhere, anytime without being present in class", most of the students strongly agreed by $50 \%$ that this could be one of the easy ways to access materials. On top of that, submitting assignment through online classes is more comfortable compared to face to face, which gives $44 \%$ of students agree. In contrast, the statement of "Statistical evaluation page in the LMS used for an online class provides students to measure the detailed information on their strength and weaknesses of each topic" was found to have the same value of $32 \%$ for strongly agree, agree and disagree. The table also shows that student strongly agrees on the statement which mentions online classes are more systematic than face to face classes with the highest percentage of $54 \%$. On top of that, $44 \%$ of the total number of students strongly agree that online classes instill creativity in them. However, there is a slightly disagree of $40 \%$ when it comes to integrating activities in the online platform as students faces problem in comprehending those materials. 
Table 1. Student's perception towards online classes

\begin{tabular}{|c|c|c|c|c|}
\hline Question & $\begin{array}{l}\text { SD } \\
\text { F } \\
(\%)\end{array}$ & $\begin{array}{l}\text { D } \\
\text { F } \\
(\%)\end{array}$ & $\begin{array}{l}\text { A } \\
\text { F } \\
(\%)\end{array}$ & $\begin{array}{c}\text { SA } \\
\text { F } \\
(\%)\end{array}$ \\
\hline \multirow{2}{*}{$\begin{array}{l}\text { Online class is an innovative concept and must be encouraged by every } \\
\text { university }\end{array}$} & 1 & 13 & 20 & 16 \\
\hline & $(2.0)$ & $(26.0)$ & $(40.0)$ & $(32.0)$ \\
\hline \multirow{2}{*}{ Online classes helped students to learn at their own pace and it's flexible. } & 1 & 18 & 27 & 4 \\
\hline & $(2.0)$ & $(36.0)$ & $(54.0)$ & $(8.0)$ \\
\hline \multirow{2}{*}{ Online classes make the learning process easier to students } & 4 & 10 & 24 & 12 \\
\hline & $(8.0)$ & $(20.0)$ & $(48.0)$ & $(24.0)$ \\
\hline \multirow{2}{*}{$\begin{array}{c}\text { Students access lecture notes anywhere, anytime without being present in } \\
\text { class. }\end{array}$} & 1 & 4 & 20 & 25 \\
\hline & $(2.0)$ & $(8.0)$ & $(40.0)$ & $(50.0)$ \\
\hline \multirow{2}{*}{$\begin{array}{l}\text { It is easy to submit the assignments through online classes compare to } \\
\text { face to face classes }\end{array}$} & 2 & 5 & 22 & 21 \\
\hline & $(4.0)$ & $(10.0)$ & $(44.0)$ & $(42.0)$ \\
\hline \multirow{2}{*}{ Students received timely feedback on their work easily. } & 4 & 10 & 24 & 12 \\
\hline & $(8.0)$ & $(20.0)$ & $(48.0)$ & $(24.0)$ \\
\hline \multirow{2}{*}{$\begin{array}{l}\text { Statistical evaluation page in the LMS used for online class provides } \\
\text { students to measure the detailed information on their strength and } \\
\text { weaknesses of each topic. }\end{array}$} & 2 & 16 & 16 & 16 \\
\hline & $(4.00)$ & $(32.0)$ & $(32.0)$ & (32.0) \\
\hline \multirow{2}{*}{ Online classes are more systematic than face to face classes. } & 1 & 10 & 12 & 27 \\
\hline & $(2.0)$ & $(20.0)$ & $(24.0)$ & $(54.0)$ \\
\hline \multirow{2}{*}{$\begin{array}{l}\text { Online classes provide better opportunity to use technology and related } \\
\text { resources. }\end{array}$} & 5 & 10 & 21 & 14 \\
\hline & $(10.0)$ & $(20.0)$ & $(42.0)$ & $(28.0)$ \\
\hline \multirow{2}{*}{$\begin{array}{l}\text { Student feels that activities integrated in the online platform increases } \\
\text { their understanding of the course material. }\end{array}$} & 6 & 20 & 15 & 9 \\
\hline & $(12.0)$ & $(40.0)$ & $(30.0)$ & (18.0) \\
\hline \multirow{2}{*}{$\begin{array}{l}\text { Students learn how to be organized through online classes and it promotes } \\
\text { creativity }\end{array}$} & 0 & 14 & 14 & 22 \\
\hline & $(0.0)$ & $(28.0)$ & $(28.0)$ & (44.0) \\
\hline
\end{tabular}

Table 2. Effects in enhancing active participation and communication skills

\begin{tabular}{|c|c|c|c|c|}
\hline Question & $\begin{array}{c}\text { SD } \\
\text { F } \\
(\%)\end{array}$ & $\begin{array}{l}\text { D } \\
\text { F } \\
(\%)\end{array}$ & $\begin{array}{l} \\
\text { F } \\
(\%)\end{array}$ & $\begin{array}{c}\text { SA } \\
\text { F } \\
(\%)\end{array}$ \\
\hline \multirow{2}{*}{$\begin{array}{l}\text { Students can find information actively in the eLearning platform created by the } \\
\text { lecturer. }\end{array}$} & 2 & 9 & 29 & 10 \\
\hline & $(4.0)$ & $(18.0)$ & $(58.0)$ & $(20.0)$ \\
\hline \multirow{2}{*}{ Students could be express their opinions in an online class. } & 2 & 18 & 20 & 10 \\
\hline & $(4.0)$ & $(36.0)$ & $(40.0)$ & $(20.0)$ \\
\hline \multirow{2}{*}{$\begin{array}{l}\text { Online classes give the opportunity students to read, download/play videos } \\
\text { (educational content) and review the content for several times }\end{array}$} & 5 & 16 & 21 & 8 \\
\hline & $(10.0)$ & $(32.0)$ & $(42.0)$ & $(16.0)$ \\
\hline \multirow{2}{*}{$\begin{array}{l}\text { Online learning gives opportunity for every student to share their opinion and } \\
\text { feedback through the tools which is used by the lecturer and increases the } \\
\text { opportunity to receive the feedback from the lecturer. }\end{array}$} & 1 & 13 & 28 & 8 \\
\hline & $(2.0)$ & $(26.0)$ & $(56.0)$ & (16.0) \\
\hline \multirow{2}{*}{$\begin{array}{l}\text { Online classes enable student to attend more frequently than face to face } \\
\text { method. }\end{array}$} & 4 & 19 & 18 & 9 \\
\hline & $(8.0)$ & $(38.0)$ & $(36.0)$ & $(18.0)$ \\
\hline \multirow{2}{*}{$\begin{array}{l}\text { Online classes enhance participation where even for those students who are } \\
\text { shy to speak up in face to face class. }\end{array}$} & 6 & 5 & 21 & 18 \\
\hline & $(12.0)$ & $(10.0)$ & $(42.0)$ & $(36.0)$ \\
\hline \multirow{2}{*}{$\begin{array}{l}\text { Students would have gained more interpersonal skills and the ability to work in } \\
\text { a team. }\end{array}$} & 1 & 13 & 28 & 8 \\
\hline & $(2.0)$ & $(26.0)$ & $(56.0)$ & $(16.0)$ \\
\hline \multirow{2}{*}{ It is easier for students to have communication with the lecturer. } & 1 & 21 & 17 & 11 \\
\hline & $(2.0)$ & $(42.0)$ & $(34.0)$ & $(22.0)$ \\
\hline \multirow{2}{*}{$\begin{array}{l}\text { Students receive better explanation of the course content compared with } \\
\text { meeting face-to-face with the lecturer. }\end{array}$} & 6 & 21 & 15 & 8 \\
\hline & $(12.0)$ & $(42.0)$ & $(30.0)$ & $(16.0)$ \\
\hline \multirow{2}{*}{$\begin{array}{l}\text { Online class enhances students speaking and listening skills by using blogs, } \\
\text { chats, and discussion room }\end{array}$} & 2 & 11 & 17 & 20 \\
\hline & $(4.0)$ & $(22.0)$ & $(34.0)$ & $(40.0)$ \\
\hline
\end{tabular}


Based on table 2, 58\% out of a total number of students who participated in this study agrees to the statement "Students can find information actively in the e-Learning platform created by the lecturer." Student agreed as for two statements; which are students could give feedback through online learning of $42 \%$ and students can utilize the embedded videos and other content for several times which gives $56 \%$. In comparison to the percentages in the table, "It is easier for students to have communication with the lecturer" and "Students receive a better explanation of the course content compared with meeting face-to-face with the lecturer" show a significant increase on disagree value with $42 \%$ as compared to "Online classes enable students to attend more frequently than face to face method" with only $38 \%$. There were $42 \%$ of students agreed that online classes enhance participation were even for those students who are shy to speak up in a face to face class. Based on a more significant proportion of the students, $56 \%$ of the sample agreed that "Students would have gained more interpersonal skills and the ability to work in a team. Finally, $40 \%$ of students strongly agreed that online class could enhance their speaking and listening skills through blogs, chat and discussion room.

\section{Discussion and Conclusion}

In this study, two research questions need to be answered: to measure student's perception of online class, and to evaluate the effects on participation and communication. The findings portray that accessibility of materials that students can access at their convenience gives a positive perception towards students. This statement is in line with the previous study by Al-Dosari [27], which mentioned that online courses users who enrolled considered accessibility an advantage for students e-learning. Moreover, students find that online classes enhance creativity and make them be organized. As said by Badali, Dana Mazrae, Farokhi Tirandaz, and Herfedoost [28] conduct e-learning and having an assessment through that develops student's creativity to be more creative and original. Furthermore, students felt that online class is an innovative concept which will be good if it is being implemented in every university. In the end, it is to give a positive reflection as said that it is a good practice.

Additionally, when it comes to the effectiveness of active participants and communication, students agreed to a greater extent that online classes enhance speaking and listening skills. Similar studies found that participants gain an advantage in speaking and listening skills in Skype-based classes [29], Furthermore, students agreed that through online classes, it enhances participation and as well as communication. This statement shows that students are active in participating when it comes to the online class, as even those who are shy to speak up increase communication skills in the said instruction. This finding can be related to the previous study by Al-rahmi et al. [30]. In his research, it was found that online classes improve student's interaction with peers and lecturers and enhance communication skills.

Besides, Cakiroglu [31], also explains that there is a highly satisfactory percentage in terms of assessing communication between teachers and students in online classes. The study Kanaan et al. [32] mentioned that students did not receive timely feedback from teachers, which contradicts the findings generated from this study. This study gives an excellent opportunity for students to share their opinion and feedback with the lecturer; at the end enhances both communication skills and active participation. The results show that online classes improve participation and communication skills even though they are shy and afraid to speak up. This statement is in line with Soliman [33], study on allowing introverts to interact effectively through an e-learning platform. It shows that students were positive towards enhancing the collaboration of teamwork.

To conclude, online classes can be an efficient tool in enhancing student's collaboration and active participation, especially for English for Professional Communication class. The usage of e-learning tools in teaching and learning, for example, online classes can give students to increase their participation as well as communication skills. Nevertheless, this study's finding reveals that most students have positive feelings towards their perception and experience with online classes in terms of communication skills. It shows that students have a positive attitude and their anxiety reduces particularly in terms of communicating or providing an opinion. This statement is also related to the study by Loderer et al. [34], on using online class gives the feel of pleasure and lessen anxiety. Flexibility, as well as accessibility, can increase students' active participation, which is somehow related to the finding in this study. Based on the results, it is recommended that higher educational institutions should encourage and impose the online class method widely. Eventually, this can promote and strengthen the collaboration of technology skills in teaching and learning journey. Exposure to more interactive tools in online classes will gives students to think wider and exciting learning styles are leveraged which is in line with the previous study done by Raja and Nagasubramani [35]. To some extent, this finding develops the use of online classes for English for Professional Communication subjects to facilitate active participation and increase communication skills.

\section{REFERENCES}

[1] Di Vaio. A., Boccia. F., Landriani. L., Palladino. R, "Artificial intelligence in the agri-food system: Rethinking 
sustainable business models in the COVID-19 scenario". Sustainability, Vol 12, No 12, p. 4851, 2020.

[2] Alhom. M., Courtney. M, "Educational data mining: A case study perspectives from primary to university education in Australia”, Information Technology and Computer Science, Vol. 10, No. 2, pp.1-9, 2018. DOI:10.5815/ijitcs.2018.02.01

[3] Abdelmalak, "Web 2.0 Technologies and Building Online Learning Communities: Students' Perspectives”, Journal of asynchronous learning networks, Vol.19, No 2, pp. 1-20, 2015. DOI: http://dx.doi.org/10.24059/olj.v19i2.413

[4] Al-Hassan. S., Shukri. N, "The Effect of Blended Learning in Enhancing Female Students' Satisfaction in the Saudi Context", English Language Teaching, Vol. 10, No. 6, pp.190-203, 2017. DOI:https://doi.org/10.5539/elt.v10n6p1 90

[5] Danesh. A., Bailey. A., Whisenand. T, "Technology and Instructor-Interface Interaction in Distance Education", International Journal of Business and Social Science, Vol. 6 , No.2, pp.39-47, 2015.

[6] Chiaha. G., Eze. J. U., Ezeudu. F. O, 'Education students' access to E-learning facilities in universities south-east of Nigeria”. Information and Knowledge Management, Vol. 3, No. 10, pp. 32-41, 2013.

[7] Rhode. J., Richter. S., Gowen. P., Miller. T., Wills. C, "Understanding Faculty Use of the Learning Management System", Online Learning, Vol. 21, No. 3, pp. 68-86, 2017. DOI:10.24059/olj. v21i3.1217

[8] Yadav. G, "Reflection on Virtual Classes: Spirit of the Time", International Journal of Advanced Research, Vol .4, No. 4. DOI: 1162-1167,2016.

[9] Agustina. N., Budhisantosa. N, "Development of e-learning for English class". In SHS Web of Conferences, Vol. 42, No.00077. pp 1-7, 2018. DOI: https://doi.org/10.1051/shsco $\mathrm{nf} / 20184200077$

[10] Sangrà. A., Vlachopoulos. D., Cabrera. N, "Building an inclusive definition of e-learning: An approach to the conceptual framework", The International Review of Research in Open and Distributed Learning, Vol. 13, No. 2, pp. 59-145.2012. DOI:10.19173/irrodl.v13i2.1161

[11] Singh. V., Thurman. A, "How many ways can we define online learning? A systematic literature review of definitions of online learning (1988-2018)", American Journal of Distance Education, Vol. 33, No. 4, pp. 289-306. 2019.

[12] Cojocariu. V.-M., Lazar. I., Nedeff. V., Lazar. G, "SWOT analysis of e-learning educational services from the perspective of their beneficiaries", Procedia-Social and Behavioral Sciences, Vol. 116, No.0, pp.1999-2003, 2014.

[13] Aydin. H, "Interaction between Teachers and Students in Online Learning", Journal of Environmental Protection and Ecology, Vol. 14 No. 3A, pp. 1337-1352, 2103.

[14] L. Kolås, "Application of interactive videos in education," International Conference on Information Technology Based Higher Education and Training (ITHET), Lisbon, 2015, pp. 1-6, DOI: 10.1109/ITHET.2015.7218037.

[15] Sanjay. G., Narayana. T, "Teaching Speaking Skills Through Motivational Strategies", Research Journal of English (RJOE), Vol.5, No. 2,2020
[16] Price. L, "Technology-enhanced learning and teaching in higher education: What is 'enhanced' and how do we know? A critical literature review", Learning, Media and Technology, Vol.39, No. 1, pp. 6-36. 2014. DOI:10.1080/17439884.2013.770404

[17] Koohang. A., Paliszkiewicz. J., Klein. D., Horn Nord. J, "The importance of active learning elements in the design of online courses", Online Journal of Applied Knowledge Management (OJAKM), Vol. 4, No. 2, pp. 17-28, 2016.

[18] Cole. A. W, "Testing the impact of student preference for face-to-face communication on online course satisfaction", Western Journal of Communication, Vol.80, No.5, pp. 619-637, 2016. DOI:10.1080/10570314.2016.1186824

[19] Hase. S, "Heutagogy and e-learning in the workplace: Some challenges and opportunities", Journal of Applied Research in Workplace E-learning, Vol. 1, No. 1, pp. 43-52, 2009. DOI: 10.5043/impact.13

[20] Thamarana. S, "Role of E-learning and Virtual Learning Environment in English language learning", $4^{\text {th }}$ Annual International Conference, ELTAI Tirupati, pp.61-62, 2016.

[21] Felix. A, "Awareness of Students towards E-Learning in Education”, Purakala Journal, Vol. 31, No. 15, pp.620-626, 2020 DOI: http://purakala.com/index.php/0971-2143

[22] Salbego. N., Tumolo, "Skype Classes: Teachers and Students' Perceptions on Synchronous Online Classes in Relation to Face-To-Face Teaching and Learning", International Journal of Language and Applied Linguistic, Vol. 1, No. 3, pp. 36-45, 2015.

[23] Joksimović. S., Gašević. D., Kovanović. V., Riecke. B. E., Hatala. M, "Social presence in online discussions as a process predictor of academic performance". Journal of Computer Assisted Learning, Vol. 31, No. 6, pp. 638-654, 2015. DOI: $10.1111 /$ jcal.12107

[24] Picciano. A. G, "Theories and frameworks for online education: Seeking an integrated model", Online Learning Journal, Vo. 21, No. 3, 2017. DOI: https://doi.org/10.24059 /olj.v21i3.1225

[25] Xu. D., Huang. W. W., Wang. H., Heales. J, "Enhancing e-learning effectiveness using an intelligent agent-supported personalized virtual learning environment: An empirical investigation, Information \& Management, Vol. 5, No. 14, pp. 430-440, 2014.

[26] Goldsmith. L, "Digital feedback: An integral part of the online classroom", Distance Learning, Vol. 11, No. 2, pp. 33-40, 2014.

[27] Al-Dosari. H, "Faculty Members and Students Perceptions of E-Learning in the English Department: A Project Evaluation". Journal of Social Sciences, Vol. 7, No.3, pp. 391-407, 2011. DOI:10.3844/jssp.2011.391.407

[28] Badali. M., Dana-Mazra'e. A., Farokhi-Tirandaz. S., Herfeh-Doost. M, "The Impacts of Using Electronic Portfolio in Students' Creativity", Innovation and Creativity in Humanities, Vol. 3, No. 12, pp. 45-68, 2013.

[29] Verjano. A. C, "Using Skype in a Primary Class: a case study", Bellaterra Journal of Teaching and Learning Language and Literature. Vol. 6, No. 2, 2013, pp. 49-68

[30] Al-Rahmi. W. M., Othman. M. S., Yusuf. L. M, "Social 
Media for Collaborative Learning and Engagement: Adoption Framework in Higher Education Institutions in Malaysia", Mediterranean Journal of Social Sciences. Vol. 16, No. 4, pp. 2015. DOI:10.5901/mjss. 2015.v6n3s1p246

[31] Cakiroglu. U, "Evaluating students' perspectives about virtual classrooms with regard to Seven Principles of Good Practice", South African Journal of Education, Vol. 34, No. 2, pp. 1-19, 2014. DOI:10.15700/201412071201

[32] Kanaan. R., Gharaibeh. A, "The Impact of Knowledge Sharing Enablers on Knowledge Sharing Capability: An Empirical Study on Jordanian Telecommunication Firms". European Scientific Journal, Vol. 9, No. 22, pp. 237-258, 2013.
[33] Soliman. N. A, "Using e-learning to develop EFL students' language skills and activate their independent learning", Creative Education, Vol.5, No.10, pp.752-757, 2014. DOI: http:// dx.doi.org/10.4236/ce.2014.510088

[34] Loderer. K., Pekrun. R., Lester. J. C, "Beyond cold technology: A systematic review and meta-analysis on emotions in technology-based learning environments". Learning and instruction, p. 101162, 2018. DOI: https://doi.org/10.1016/j.learninstruc.2018.08.002

[35] Raja. R., Nagasubramani. P. C, Impact of modern technology in education. Journal of Applied and Advanced Research, Vol. 3, No. 1, pp. 33-35, 2018. DOI: http://dx.doi.org/10.21839/jaar.2018.v3iS1.165 